Reprod. Nutr. Dévelop., 1982, 22 (1 B), 209-215.

\title{
A biochemical model for neurite outgrowth during brain development
}

\author{
J. FRANCON, A. MARECK, Ana Maria LENNON, Arlette FELLOUS, J. NUNEZ
}

with the technical assistance of Françoise CHANTOUX and Jeanine OSTY

INSERM, Unité Thyroïde,

78, rue du Général-Leclerc, 94270 Bicêtre, France.

Summary. Maximal amounts of tubulin in rat brain are observed during the 3 to 10-day postnatal period. The rates of in vitro tubulin polymerization are very low at these stages of development; they increase thereafter during the second postnatal week, reaching a maximum at adulthood.

The increased rate of polymerization could depend either on modifications in the concentration and activity of microtubule-associated proteins (MAPs), which play a crucial role in microtubule assembly in vitro, or on changes in their composition. The results show that the composition and activity of TAU proteins (MW: 58-68000) change during development. Analysis of "young " and " adult " TAU protein peptide mapping suggests that their amino acid sequence is different.

Our data indicate a good correlation between tubulin capacity to polymerize in vitro and changes in the composition and activity of TAU proteins which occur during the critical period when the neuronal network is constructed.

\section{Introduction.}

The major biological event occurring during brain development at the states of neuronal differentiation is that a given group of cells stops dividing and begins to develop neurites. Under in vitro conditions using established cell lines or primary cultures, neurite outgrowth can be triggered in appropriate culture media (Amano et al., 1972). In these conditions, the microtubules are organized differently, depending on whether the cell divides or differentiates; the same pool of tubulin, the basic microtubular subunit, seems to be used to form either the mitotic spindle or the bundles of microtubules concentrated in the neurites. Moreover, neurite outgrowth can be blocked by various antimitotic drugs such as colchicine (Yamada et al., 1970) which binds to free tubulin and prevents its polymerization to microtubules. According to Jockusch et al. (1979) microtubule formation indicates an overall differentiation of fibrous brain glial cells and neuronal cells. Since the tubulin present in the neuronal network of the mature brain represents 
80 to 90 p. 100 of its total pool (Morgan and Seeds, 1975) and since its polymerization seems to be a prerequisite for neurite outgrowth, we have taken this parameter as a molecular marker of brain differentiation.

\section{Results.}

1. Tubulin concentration and polymerization during brain development. We first had to determine whether neurotubulin is assembled into neurotubules as soon as it is synthesized, i.e. is the concentration of tubulin or its ability to assemble the rate limiting factor in the formation of the microtubules ? In a previous study (Fellous et al., 1975) we had shown that since maximal amounts of tubulin were present during the critical period of neuronal maturation, the tubulin content of rat brain was as high just after birth as the adult stage.

We therefore considered the second possibility that since sufficient amounts of neurotubulin were present just before the onset of brain maturation, a specific signal at a given stage could induce its polymerization to microtubules, thereby permitting intensive neurite growth.

The methodology used to study this question was based on two observations : (i) during the preparation of brain homogenates at low temperature $\left(4^{\circ} \mathrm{C}\right)$ almost all the tubulin, present in a polymerized form in the intact brain, dissociated to free soluble $6 \mathrm{~S}$ dimer, (ii) free soluble tubulin could be reassembled

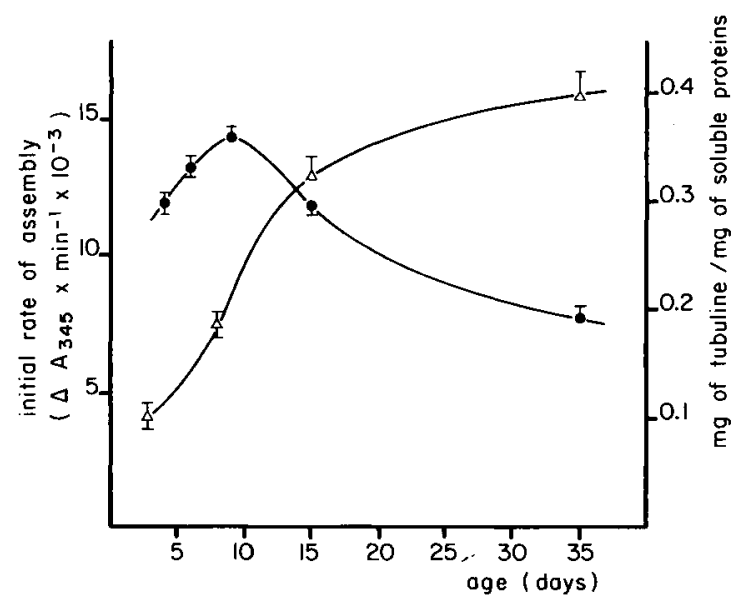

FIG. 1. - Changes im tubulin concentration $(\bullet-\bullet)$ and in initial rate of tubulin assembly $(\Delta-\Delta)$ in rat brain supernatants during postnatal development. The supernatants were obtained after homogenization of rat brain at $4^{\circ} \mathrm{C}$ in a reassembly buffer $(0.1 \mathrm{M}$ MES $(\mathrm{pH} 6.5), 1 \mathrm{mM}$ GTP, $0.5 \mathrm{mM} \mathrm{MgCl} 2,1 \mathrm{mM}$ EGTA, $0.1 \mathrm{mM}$ EDTA, $1 \mathrm{mM} \beta \mathrm{MSH}$ ) and centrifugation (105000 $\times \mathrm{g}$, $1 \mathrm{~h}, 4^{\circ} \mathrm{C}$ ). Glycerol (final concentration $4 \mathrm{M}$ ) was added to the supernatant. The concentration of tubulin was measured using a colchicine binding assay (Fellous et al., 1975). Turbidity time courses (Gaskin et al., 1974) were measured for various dilutions of the supernatants and the initial rate of polymerization was calculated for a given concentration of tubulin $(0.9 \mathrm{mg} / \mathrm{ml})$ at different stages of development (Fellous et al., 1979). Each point represents the mean of at least 5 experiments \pm SEM. 
in vitro to microtubule-like structures (Weisenberg, 1972). Using this procedure with crude rat brain supernatants, we had previously shown (Francon et al., 1978) that in vitro microtubule assembly could be estimated quantitatively by the turbidimetric method of Gaskin et al. (1974) with highly reproducible results. Kinetic experiments were performed with various dilutions of brain homogenate supernatants at different stages of postnatal development (Francon et al., 1978). These results (fig. 1) showed that at early postnatal stages the initial rate of tubulin polymerization into microtubules was minimal but that polymerization capacity increased rapidly during the first to postnatal weeks, reaching a maximum during adult life. Other parameters of in vitro microtubule assembly also changed during development ; for example, there were longer lag periods in the polymerization reaction and higher values of the critical concentration were observed (Francon et al., 1978).

The minimal conclusions which can be drawn from these results are : (i) the highest tubulin contents are observed during, or even before, the early stages of neuronal differentiation, (ii) neurotubulin is not assembled into microtubules as soon as synthesized since the maximal increase in assembly rate was seen during the second postnatal week, whereas maximal tubulin content was observed during the 3 to 10-day postnatal period (fig. 1).

2. The role of microtubule-associated proteins during brain development. Control experiments showed that the low assembly rates observed at early stages of neuronal differentiation were not the result of the presence of an inhibitor but rather the lack or limiting concentration of factors inducing microtubule assembly just after birth (Francon et al., 1978). This latter possibility was suggested by analysis of the kinetic experiments which showed the assembly step of nucleation or initiation to be limiting. Several protein factors, microtubule-associated proteins (MAPs) (Sloboda et al., 1975), copolymerize with tubulin and are required for the initiation process (Johnson and Borisy, 1977). MAPs are not absolutely necess-

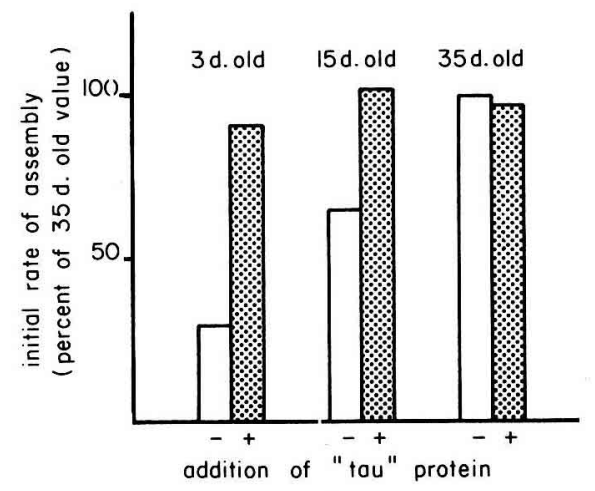

FIG. 2. - Effect of the addition of MAPs on the initial rate of microtubule assembly in rat brain supernatants at different stages of development. Supernatants were obtained as described in figure 1 from 3, 15, and 35-day old rat brains. Initial rates of polymerization $(\Delta A 345 \mathrm{~nm} / \mathrm{min}$.) were measured for a given tubulin concentration $(1.32 \mathrm{mg} / \mathrm{ml})$ and expressed as a $\mathrm{p}$. 100 of the $35-$ day odl value in the absence $(-)$ and the presence $(+)$ of thermostable MAPs $(350 \mu \mathrm{g} / \mathrm{ml})$. 
ary for the elongation step of microtubule assembly (Murphy et al., 1977). Consequently, the effect of adding these factors was studied on 3, 15 and 35-day old rat brain supernatants. Figure 2 shows that the addition of MAPs had no effect on the 35-day old preparations, whereas maximal assembly rates were recovered on 3 and 15-day old brain supernatants. Similarly, the period of polymerization lag also decreased (Francon et al., 1978). Since MAPs appear to play a crucial role in the nucleating process and can restore normal assembly rates, we assumed that their concentration, activity or composition, or several of these factors, changed during the period of neuronal differentiation.

3. Changes in MAPs composition and activity during brain development. In a first group of experiments in vitro, assembled microtubules were prepared at different stages of rat brain development. MAPs were then prepared by thermic denaturation of microtubules (Fellous et al., 1977). Figure 3 shows that the MAPs composition changes during brain development. Proteins migrating with the same mobility as $\mathrm{MAP}_{2}$ (Sloboda et al., 1976) and TAU (Cleveland et al., 1977 a, b) are present at all ages studied. $\mathrm{MAP}_{2}$ does not seem to change, whereas the bands present in the TAU group position are markedly modified during development. At the adult stage, TAU is composed of four closely-spaced bands, as described by Cleveland et al. (1977 a). On day 3, only two large bands are present; none of them has migrated to the position of the adult bands. Other data also showed that the transition between the 3-day old status and the adult one is progressive (Nunez et al., 1980) ; for example, at 15. postnatal days, the TAU group contains a mixed population of young and adult entities (fig. 3). These differences were found in several different experiments carried out in the presence of protease inhibitors to rule out the possibility that these changes were artefactually produced by proteolytic breakdown.

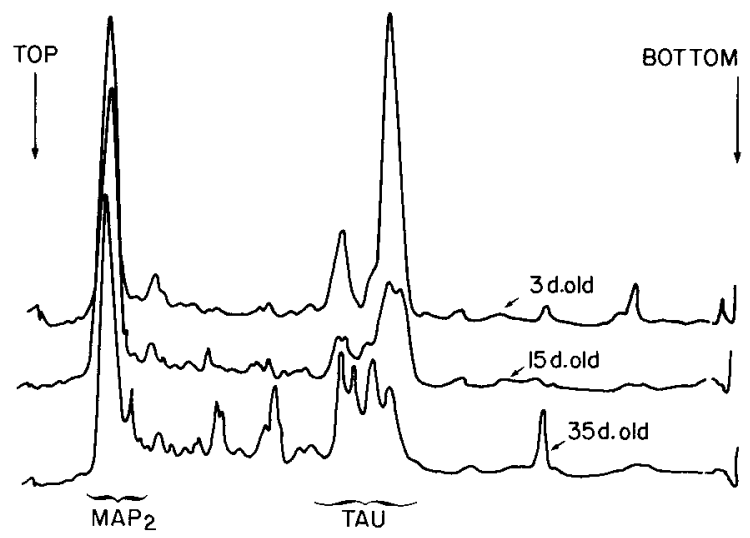

FIG. 3. - SDS-PAGE patterns of thermostable MAPS from 3, 15 and 35-day old rat brains. Aliquots of thermostable MAPs were dialysed overnight against the following buffer : $10 \mathrm{mM}$ Tris$\mathrm{HCl} \mathrm{pH} \mathrm{8.0,1} \mathrm{mM} \mathrm{EDTA,} \mathrm{2,5} \mathrm{p.} 100$ SDS and $5 \mathrm{p} .100 \beta$-mercaptoethanol, and then bolled for $5 \mathrm{~min}$. Different aliquots $(5-20 \mu \mathrm{g})$ were then analysed on polyacrylamide gradient (4-15 p. 100) slab gels containing 0.2 p. $100 \mathrm{SDS}, 0.04 \mathrm{M}$ Tris, $0.02 \mathrm{M}$ sodium acetate, pH 7.4, $2 \mathrm{mM}$ EDTA and electrophoresed for $5 \mathrm{hrs}$ at $150 \mathrm{~V}$ (constant voltage) in the same buffer. The gels were then stained with Coomassie R250 blue in 10 p. 100 acetic acid. Densitometer tracings were obtained from the same slarb gel. 
Since the MAPs analysis clearly showed that the composition of the TAU group was modified, and since these proteins play an important role in vitro in the assembly process (Cleveland et al., $1977 \mathrm{~b}$ ), they were purified by gel filtration (Fellous et al., 1977) of 3 and 35-day old rat brain total MAP preparations. Figure 4 show the capacity of these two groups of proteins to induce the in vitro assembly of pure tubulin. The specific activity of 3-day old TAU is clearly lower than the adult one.



FIG. 4. - Effect of the addition of purified TAU protein from $3(0-O)$ and $(\bullet-\bullet)$ day old rat brains. Tau proteins were purified from thermostable MAPs by gel filtration on Ultrogel $\mathrm{ACA}_{34}$ (Fellous et al., 1977). The polymerization promoting activity of the same amount $10.29 \mathrm{mg} / \mathrm{ml})$ of the to types of TAU proteins were assayed with pure $6 \mathrm{~S}$ tubulin $(1 \mathrm{mg} / \mathrm{ml})$ (Francon et al., 1978).

In conclusion, both the composition and activity of TAU proteins change during brain development ; this is closely correlated with both the profile of the kinetic parameters of in vitro microtubule assembly and with the period of intensive neurite growth occurring during neuronal differentiation.

4. Is the change in MAP composition a transcriptional or translational event? - The simplest experimental approach to this question was to establish and compare the peptide map of " young " and " adult » TAU populations. After complete purification of these fractions by Ultrogel ACA 34 chromatography (Fellous et al., 1977), aliquots of each TAU preparation were subjected to partial proteolysis for varying periods of time with either $S$. aureus or chymotrypsin (Cleveland et al., $1977 \mathrm{c}$ ) ; the hydrolysates were analyzed by polyacrylamide gel electrophoresis. The results (unpublished) showed that the peptide maps of "young " and " adult " TAU differ markedly and independently of both the length of proteolysis and the proteolytic enzyme used. However, some similarities are found in the mobilities of the smaller peptides formed with chymotrypsin. Work is in progress to analyze in greater detail the peptide map of each of the individual bands of "yound " and " adult " TAU.

These results suggest that, depending on the stage of brain maturation, different genes may code for the proteins which belong to the TAU fraction. Another possibility is that genetic information on both " young " and " adult " TAU is present in the same DNA sequence but that changes occur only in those sections of the gene which are transcribed at early and late stages of development, respectively. 


\section{Conclusion.}

According to the model presented in this work, neurite outgrowth, one of the major events of neuronal differentiation, would be governed by changes in the molecular signals required for microtubule assembly. Little is known of their precise significance, although it is presumed that " young " and " old " TAU play respective roles in microtubule assembly during cell division and cell differentiation. Changes in the distribution and function of the microtubules (and of the cytoskeleton) in the different compartments of the cell might also be important factors implicated in the acquisition of other properties of the differentiating nerve cell, e.g. cell mobility and cell migration, and/or stabilization of nerve endings and synaptogenesis.

7e Réunion du groupe Développement I.N.R.A., Nouzilly/Tours, 14-15 mai 1981.

Résumé. La tubuline présente dans le réseau de connections neuronales du cerveau mature représente 80 à 90 p. 100 du pool total de cette protéine ; sa polymérisation en microtubules semble être un préalable à la croissance des neurites. Ce paramètre a été donc choisi comme marqueur moléculaire de la différentiation neuronale du cerveau de rat. Les résultats suivants sont en faveur de cette hypothèse : 1) Les teneurs maximales en tubuline sont observées pendant la période 3-10 jours après la naissance. La polymérisation in vitro de cette protéine est très faible à ces stades ; elle n'augmente qu'au cours de la deuxième semaine post-natale et n'est maximale qu'au stade adulte. 2) Cette augmentation de vitesse de polymérisation pouvait dépendre de changements dans la concentration, l'activité ou la composition en "protéines associées aux microtubules " qui jouent un rôle essentiel dans le processus d'assemblage. Diverses expériences permettaient de montrer que la compoition (et l'activité) du groupe de protéines de poids moléculaire $\sim 70000$ (facteurs TAU) change au cours du développement postnatal. 3) Des cartes peptidiques des protéines TAU « jeunes » et " adultes ", obtenues après protéolyse partielle, suggèrent que ces facteurs renferment des séquences très différentes.

En conclusion, ces résultats montrent qu'il existe une corrélation entre, d'une part, la capacité de polymérisation de la tubuline et les modifications dans la composition et l'activité des facteurs TAU qui jouent un rôle majeur dans ce processus et, d'autre part, la période critique de croissance des connections interneuronales.

\section{References}

AMANO T., RICHELSON E., NIRENBERG N. W., 1972. Neurotransmitter synthesis by neuroblastoma synthesis by neuroblastoma clones. Proc. nat. Acad. Sci. USA, 69, $258-263$.

CLEVELAND D. W., HWO S. Y., KIRSCHNER M. W., 1977 a. Purification of TAU, a microtubuleassociated protein that induces assembly of microtubules from purified tubulin. J. mol. Biol., 116, 207-225.

CLEVELAND D. W., HWO S. Y., KIRSCHNER M. W., 1977 b. Physical and chemical properties of purified TAU factor and the role of TAU in microtubule assemblu. J. mol. Biol., 116, 227-247.

CLEVELAND D. W., FISCHER S. G., KIRSCHNER M. W., LAEMLI U. K., 1977 c. Peptide mapping by limited proteolysis in sodium dodecyl sulfate and analysis by gel electrophoresis. J. biol. Chem., 252, 1102-1106. 
FELLOUS A., FRANCON J., VIRION A., NUNEZ J., 1975. Microtubules and brain development. FEBS Lett., 57, 5-8.

FELLOUS A., FRANCON J., LENNON A. M., NUNEZ J., 1977. Microtubule assembly in vitro. Purification of assembly promoting factors. Eur. J. Biochem., 78, 167-174.

FELLOUS A., LENNON A. M., FRANCON J., NUNEZ J., 1979. Thyroid hormones and neurotubule assembly in vitro during brain development. Eur. J. Biochem., 101, 365-376.

FRANCON J., FELLOUS A., LENNON A. M., NUNEZ J., 1978. Requirement for « factor(s) » for tubulin assembly during brain development, Eur. J. Biochem., 85, 43-53.

GASKIN F., CANTOR C. R., SHELANSKI M. L., 1974. Turbidimetric studies of the in vitro assembly and disassembly of porcine neurotubules. J. mol. Biol., 89, 737-758.

JOCKUSCH H., JOCKUSCH B. M., BURGER M. M., 1979. Nerve fibers in culture and their interactions with non-neural cells visualized by immunofluorescence. $J$. Cell Biol., 80, 629-641.

JOHNSON K. A., BORISY G. G., 1977. Kinetic analysis of microtubule self assembly in vitro. J. mol. Biol., 117, 1-31.

MORGAN J. L., SEEDS N. W., 1975. Tubulin constancy during morphological differentiation of mouse neuroblastoma cells. J. Cell Biol., 67, 136-145.

MURPHY D. B., JOHNSON K. A., BORISY G. G., 1977. Role of tubulin-associated proteins in microtubule nucleation and elongation. J. mol. Biol., 117, 33-52.

NUNEZ J., FRANCON L., LENNON A. M., FELLOUS A., MARECK A., 1980. The role of MAPs in microtubule assemblv. 213-225. In DE BRABANDER and DE MEY, Microtubules and microtubule inhibitors, Elsevier North Holland, Amsterdam.

SLOBODA R. D., RUDOLPH S. A., ROSENBAUM J. L., GREENGARD P., 1975. Cyclic AMP-dependent endogenous phosphorylation of a microtubule association protein. Proc. nat. Acad. Sci. USA, 72, 177-181.

SLOBODA R. D., DENTLER W. L., ROSENBAUM J. L., 1976. Microtubule-associated proteins and the stimulation of tubulin assembly in vitro. Biochemistry, 15, 4497-4505.

WEISENBERG R. C., 1972. Microtubule formation in vitro in solutions containing low calcium concentrations. Science, 177, 1104-1105.

YAMADA K. M., SPOONER B. S., WESSELS M. K., 1970. Axon growth : role of microfilaments and microtubules. Proc. nat. Acad. Sci. USA, 66, 1206-1212. 